CONSTITUTIONAL LAW-

PEACE, ORDER AND GOOD GOVERNMENT-

THE TEST OF ASPECT AND THE EMERGENCY DOCTRINEAN ALLEGORY*

And God spake unto Noah saying: "Build an Ark of two compartments and into the compartment designated by you as No. 91 place all the large animals and into the compartment designated by you as No. 92 place all the small animals." And Noah accordingly built the Ark with its two compartments and placed therein the animals as directed. And God saw what Noah had done and said: "It is good".

But Lo, some of the small animals in compartment 92 , by the process of natural growth and maturation, became big animals, whereupon Noah, mindful of the scheme of allocation in the original instructions ordained, transferred these animals to compartment 91. And God was heard to say: "It is good".

But Lo and Behold, divers of the small animals in compartment 92 became afflicted with the malady elephantiasis and grew to an enormous size, whereupon Noah, mindful as aforesaid, transferred these animals to compartment 91. But Lo and Behold again, these afflicted animals having recovered from their malady were once more restored to their normal size whereupon Noah, mindful as aforesaid, retransferred these animals to compartment 92. And God was heard to say: "It is good".

And Lord Watson, as though inspired by the Biblical text, declared: "Their Lordships do not doubt that some matters, in their origin local and provincial, might attain such dimensions as to affect the body politic of the Dominion, and to justify the Canadian Parliament in passing laws for their regulation or abolition in the interest of the Dominion. But great caution must be observed in distinguishing between that which is local and provincial, and therefore within the jurisdiction of the provincial Legislatures, and that which has ceased to be merely local or provincial, and has become a matter of national concern, in such sense as to bring it within the jurisdiction of the Parliament of Canada".1

And Viscount Haldane, very much, as he believed, under the influence of Lord Watson, in his turn declared: "In special circumstances, such as those of a great war ... an interest might conceivably become of such paramount and overriding importance as to amount to what lies outside the heads in s. 92 , and is not covered by them. . . . It has already been observed that circumstances are conceivable, such as those of war or famine, when the peace, order and good government of the Dominion might be imperilled under conditions so exceptional that they require legislation of a character in reality beyond anything provided for by the enumerated heads in either s. 92 or s. 91 itself. . . . For throughout the provisions of [the B.N.A. Act] there is apparent the recognition that subjects which would normally belong exclusively to a specifically assigned class of subject may, under different circumstances and in another aspect, assume a further significance. Such an aspect may conceivably become of paramount importance, and of dimensions that give rise to other aspects. ${ }^{2}$... [and] in a sufficiently great emergency such as that arising out of war, there is implied the power to deal

- This article represents a revised and updated version of that appearing in $197125 \mathrm{Alta}$. L. Rev.

1. A.G. of Ontario v. A.G. of Canada, [1896] A.C. 348, at 361 .

2. Re The Board of Commerce Act, 1919, [1922] 1 A.C. 191 at 197. 
adequately with that emergency for the safety of the Dominion as a whole. ... No authority other than the central government is in a position to deal with a problem which is essentially one of statesmanship. It may be that it has become clear that the crisis which arose is wholly at an end and that there is no justification for the continued exercise of an exceptional interference which becomes ultra vires when it is no longer called for. In such a case the law is laid down for distribution of powers in the ruling instrument would have to be invoked. ${ }^{3}$. . . No doubt there may be cases arising out of some extraordinary peril to the national life of Canada, as a whole, such as the cases arising out of war, where legislation is required of an order that passes beyond the heads of exclusive provincial competency. Such cases may be dealt with under the words at the commencement of s. 91, conferring general powers in relation to peace, order and good government, simply because such cases are not otherwise provided for. But instances of this ... are highly exceptional. Their Lordships think that the decision in Russell v. The Queen can only be supported today, not on the footing of having laid down an interpretation ... of the general words at the beginning of $s$. 91, but on the assumption of the Board ... that the evil of intemperance at that time amounted in Canada to one so great and so general that at least for the period it was a menace to the national life of Canada so serious and pressing that the National Parliament was called on to intervene to protect the nation from disaster. An epidemic of pestilence might conceivably have been regarded as analogous."4

And Duff C.J., faithfully articulating Haldane doctrine, in his turn was to declare: "The initial clause of section 91 has been many times considered. There is no dispute now that the exception which excludes from the ambit of the general power all matters assigned to the exclusive authority of the legislatures must be given its full effect. Nevertheless it has been laid down that matters normally comprised within the subjects enumerated in section 92 may, in extraordinary circumstances, acquire aspects of such paramount significance as to take them outside the sphere of that section. ... [But] there is only one case in which the Judicial Committee has held that legislation with regard to matters which were admittedly ex facie civil rights within a province, had by reason of exceptional circumstances acquired aspects and relations bringing them within the ambit of the introductory clause. That case is Fort Frances Pulp \& Paper Co. v. Manitoba Press. ${ }^{5}$. . . The judgment of the Privy Council in the last mentioned case laid down the principle that, in an emergency such as war, the authority of the Dominion in respect of legislation relating to the peace, order and good government of Canada may, in view of the necessities arising from the emergency, displace or overbear the authority of the provinces in relation to a vast field in which the provinces would otherwise have exclusive jurisdiction."6

And Lord Atkin, adverting to the original words of Lord Watson and approving Chief Justice Duff and quoting the expressions that had fallen from Viscount Haldane, declared: ". . . the validity of the legislation under the general words of s. 91 was sought to be established ... as being concerned with matters of such general importance as to have

\footnotetext{
3. Fort Frances Pulp and Power Co. v. Manitoba Free Press Co., [1923] A.C. 695 at 705 and 706.

4. Toronto Electric Commissioners v. Snider, [1925] A.C. 396 at 412.

5. Re The Natural Products Marketing Act, 1934, [1936] S.C.R. 398 at 416 and 422.

6. Re The Regulations Relating to Chemicals, [1943] S.C.R. 1 at 10.
} 
attained 'such dimensions as to affect the body politic,' and to have 'ceased to be merely local or provincial', and to have 'become matters of national concern.' It is interesting to notice how often the words used by Lord Watson ... have unsuccessfully been used in attempts to support encroachments on the provincial legislative powers given by $s$. 92. . . . The law of Canada on this branch of constitutional law has been stated with such force and clarity by the Chief Justice ... that their Lordships abstain from stating it afresh. . . . They consider that the law is finally settled by the current of cases cited by the Chief Justice on the principles declared by him. It is only necessary to call attention to the phrases in the various cases, 'abnormal circumstances,' 'exceptional conditions,' 'standard of necessity' (Board of Commerce case), 'some extraordinary peril to the national life of Canada,' 'highly exceptional,' 'epidemic of pestilence' (Snider's case), to show how far the present case is from the conditions which may override the normal distribution of powers in ss. 91 and 92. The few pages of the Chief Justice's judgment will, it is hoped, form the locus classicus of the law on this point, and preclude further disputes."7

And Viscount Simon, ignoring the Chief Justice, the Locus Classicus and Lord Atkin, but confronting Viscount Haldane, declared: "The first observation which their Lordships would make on this explanation of Russell's case is that the British North America Act nowhere gives power to the Dominion Parliament to legislate in matters which are properly to be regarded as exclusively within the competence of the provincial Legislature merely because of the existence of an emergency. Secondly, they can find nothing in the judgment of the Board in 1882 which suggests that it proceeded on the ground of emergency; there was certainly no evidence before that Board that one existed. . . . In their Lordships' opinion, the true test must be found in the real subject matter of the legislation: if it is such that it goes beyond local or provincial concern or interests and must from its inherent nature be the concern of the Dominion as a whole (. . .), then it will fall within the competence of the Dominion Parliament as a matter affecting the peace, order and good government of Canada, though it may in another aspect touch on matters specially reserved to the provincial legislatures. War or pestilence, no doubt, are instances; so, too, may be the drink or drug traffic, or the carrying of arms. . . . It is to be noticed that the Board in Snider's case nowhere said that $R$ ussell v. The Queen was wrongly decided. What it did was to put forward an explanation of what it considered was the ground of the decision, but in their Lordships' opinion the explanation is too narrowly expressed. True it is that an emergency may be the occasion which calls for the legislation, but it is the nature of the legislation itself, and not the existence of emergency, that must determine whether it is valid or not."8

And Lord Wright, under the influence of Viscount Haldane and ignoring Viscount Simon, in his turn declared: "On certain general matters of principle there is not, since the decision in Fort Frances . . . , any room for dispute. Under the British North America Act property and civil rights in the several provinces are committed to the provincial legislatures, but the Parliament of the Dominion in a sufficiently great emergency, such as that arising out of war, has power to deal adequately

7. A.G. of Canada v. A.G. of Ontario, [1937] A.C. 326 at 352-353.

8. A.-G. of Ontario v. Canada Temperance Federation, [1946] A.C. 193 at 205-206. 
with that emergency for the safety of the Dominion as a whole. The interests of the Dominion are to be protected and it rests with the Parliament of the Dominion to protect them. What those interests are the Parliament of the Dominion must be left with considerable freedom to judge. Again, if it be clear that an emergency has not arisen, or no longer exists, there can be no justification for the exercise or continued exercise of the exceptional powers. The rule of law as to the distribution of powers between the Parliament of the Dominion and the parliaments of the provinces comes into play."9

And Taschereau J. (as he then was) in his turn was tersely to declare: "A short reference to some of [the] cases will conclusively show that certain matters that normally belong to the provincial domain become of federal concern when by reason of abnormal circumstances a national emergency arises which, in order to be adequately dealt with, requires the total efforts of the country as a whole. ... In order however to vest in the federal Parliament the necessary authority to deal with such matters, there must be an emergancy."10

And Lord Morton, having advisedly compared and evaluated the opposing positions taken by Viscount Simon and Lord Atkin, declared in terms of the latter: "Their Lordships think it sufficient to say . . . that the [legislation] now under consideration relates to civil rights within each of the provinces and that .... the facts [do not] lead to the conclusion that there exist in the present case the conditions which may override the normal distribution of powers in ss. 91 and 92."11

And Cartwright J. (as he then was), ignoring Viscount Haldane, Chief Justice Duff, the Locus Classicus, and Lord Atkin, in accents of apparent finality declared: "In Johannesson . . . this court (...) adopted as the true test, to be applied in determining whether a subject-matter falls within the legislative authority of Parliament under the general words at the opening of s. 91, that formulated by Viscount Simon .... in the following words: 'In their Lordships' opinion, the true test must be found in the real subject-matter of the legislation: if it is such that it goes beyond local or provincial concern or interests and must from its inherent nature be the concern of the Dominion as a whole (. . .), then it will fall within the competence of the Dominion Parliament as a matter affecting the peace, order and good government of Canada, though it may in another aspect touch upon matters specially reserved to the provincial Legislatures.' I find it difficult to suggest a subject-matter of legislation which more clearly goes beyond local or provincial interests and is the concern of Canada as a whole than the development, conservation and improvement of the National Capital Region. . . . Adopting the words of the learned trial judge, it is my view that the Act 'deals with a single matter of national concern." "12

And lastly and resolutely, Ritchie J., expressing the sense of the conclusions at which he and four of his brothers had arrived, declared: The Chief Justice's "comprehensive review of the authorities satisfies me that the [validity of] the Anti-Inflation Act ... must depend upon whether or not the legislation was enacted to combat a national economic emergency. I use the phrase 'national emergency' in the sense in which I

9. Co-operative Committee on Japanese Canadians v. A.G. of Canada, [1947] A.C. 87 at 101.

10. Re Validity of Wartime Leasehold Regulations, [1950] S.C.R. 124 at 138 and 140.

11. Canadian Federation of Agriculture v. A.G. of Quebec, [1951] A.C. 179 at 198.

12. Munro v. National Capital Commission, (1966), 57 D.L.R. (2d) 753 at 758-759. 
take it to have been used by Lord Wright. ... In [the Japanese Canadians and Wartime Leasehold] cases the 'emergency' was occasioned by war and the aftermath of war, but I see nothing to exclude the application of the principles there enunciated from a situation created by highly exceptional economic conditions prevailing in times of peace. In my opinion such conditions exist where there can be said to be an urgent and critical situation adversely affecting all Canadians and being of such proportions as to transcend the authority vested in the Legislatures of the provinces and thus presenting an emergency which can only be effectively dealt with by Parliament in the exercise of the powers . . . 'to make laws for the peace order and good government of Canada.' The authority of Parliament in this regard is, in my opinion, limited to dealing with critical conditions and the necessity to which they give rise and must perforce be confined to legislation of a temporary character. I do not consider that the validity of the Act rests upon the constitutional doctrine exemplified in earlier decisions of the Privy Council ... and generally known as the 'national dimension' or 'national concern' doctrine. It is not difficult to envisage many different circumstances which could give rise to national concern, but at least since the Japanese Canadians case, I take it to be established that unless such concern is made manifest by circumstances amounting to a national emergency, Parliament is not endowed under the cloak of the 'peace, order and good government' clause with the authority to legislate in relation to matters reserved to the provinces. . . The source of the federal power in relation to the AntiInflation Act must, in my opinion, be found in the 'peace, order and good government' clause, and the aura of federal authority to which that clause relates can in my view only be extended so as to invade the provincial area when the legislation is directed to coping with a genuine emergency in the sense to which I have made reference." 13

And what God (or the ghost of Sir John A. Macdonald) said, one's own politics will determine.

-DR. ALEXANDER SMITH, Q.C.**

13. Reference Re Anti-Inflation Act, (1976), 68 D.L.R. (3d) 452 at 506-507 and 508.

* Professor Emeritus of Law, University of Victoria.

\section{SOVEREIGNTY AND ECOLOGY}

"There are strange things done in the midnight sun

By the men who toil for gold;"

Robert Service

If Canadians consider Canadian sovereignty desirable, its continuance is threatened by the problems in the transportation of northern gas and oil.

"When out of the night, which was fifty below, and into the din and the glare,

There stumbled a miner fresh from the creeks, dog-dirty, and loaded for bear."

Robert Service

While lecturing in the greater Los Angeles area a decade ago, the 